\title{
Surface modifications based on the cyanobacterial siderophore anachelin: from structure to functional biomaterials design
}

\author{
Karl Gademann · Joanna Kobylinska • \\ Jean-Yves Wach · Tom M. Woods
}

Received: 7 November 2008/Accepted: 23 March 2009/Published online: 7 April 2009

(C) Springer Science+Business Media, LLC. 2009

\begin{abstract}
This review describes the design, synthesis and evaluation of novel catechol based anchors for surface modification. The anachelin chromophore, the catecholate fragment of the siderophore anachelin from the cyanobacterium Anabaena cylindrica, allows for the immobilization of polyethylene glycol (PEG) on titania and glass surfaces thus rendering them protein resistant and antifouling. It is proposed that catecholate siderophores constitute a class of natural products useful for surface modification similar to dihydroxyphenylalanine and dopamine derived compounds found in mussel adhesive proteins. Second-generation dopamine derivatives featuring a quaternary ammonium group were found to be equally efficient in generating antifouling surfaces. The anachelin chromophore, merged via a PEG linker to the glycopeptide antibiotic vancomycin, allowed for the generation of antimicrobial surfaces through an operationally simple dip-and-rinse procedure. This approach offers an option for the prevention of nosocomial infections through antimicrobial implants, catheters and stents. Consequences for the mild
\end{abstract}

K. Gademann $(\bowtie) \cdot$ J. Kobylinska $\cdot$ J.-Y. Wach .

T. M. Woods

Chemical Synthesis Laboratory (SB-ISIC-LSYNC), Swiss

Federal Institute of Technology (EPFL), 1015 Lausanne,

Switzerland

e-mail: karl.gademann@epfl.ch

URL: http://lsync.epfl.ch generation of functional biomaterials are discussed and novel strategies for the immobilization of complex natural products, proteins and DNA on surfaces are presented.

Keywords Natural products - Siderophores · Surface chemistry $\cdot$ Biomaterials .

Organic synthesis

\section{Introduction}

Cyanobacteria (also known as blue-green algae) are prokaryotic photoautotrophs that populate many aquatic and terrestrial habitats including tropical waters, arctic ice, rocks (endolithic) and the fur of polar bears (Herrero and Flores 2008). It is thought that these organisms have populated the earth for around 3.5 billion years and that they may be responsible for the introduction of oxygenic photosynthesis on our planet. Cyanobacteria face ecological pressure on one side from competing organisms, particularly from other photoautotrophs but also from bacteria and fungi, and on the other hand from grazers such as crustaceans and insects which feed on cyanobacterial cells, filaments and mats (Herrero and Flores 2008). One chemical approach to secure an evolutionary advantage in these competitive aquatic environments is the production of chemical compounds for deterrence purposes (Burja et al. 2001; 
Luesch et al. 2002; Gademann and Portmann 2008). Cyanobacteria thus devote a large part of their genome to the production of such metabolites and many different compounds have been isolated and characterized from these organisms (Carmichael 1992, 1994; Namikoshi and Rinehart 1996; Burja et al. 2001; Luesch et al. 2002; Harada 2004; Singh et al. 2005; Gademann and Portmann 2008). For example, in the context of our search for novel lead structures (Gademann 2006; Bonazzi et al. 2007) we have isolated and characterized chlorinated alkaloids such as nostocarboline (Becher et al. 2005, 2009; Blom et al. 2006; Barbaras et al. 2008; Portmann et al. 2009), non-ribosomally produced microcystins (Christiansen et al. 2008) and ribosomally-produced heterocyclic peptides such as the aerucyclamides (Portmann et al. 2008a, b).

Whereas many of these compounds are thought to serve offensive purposes (e.g., by impacting the growth of competitors or grazers or by rendering cyanobacteria less attractive as a food source) there are also secreted compounds that facilitate growth through improving nutrient uptake. An essential nutrient for microorganisms is iron, which is highly prevalent in aquatic systems but only as insoluble iron oxide hydrates making it difficult for organisms to sequester (Crichton 2001). In order to acquire enough iron, cyanobacteria (as well as many other prokaryotes) produce siderophores, compounds that are able to chelate iron (Keller-Schierlein et al. 1964; Raymond et al. 1984; Drechsel and Jung 1998). Cyanobacteria produce several different types of siderophores such as schizokinen (Goldman et al. 1983; Lammers and Sanders-Loehr 1982), the synechobactins (Ito and Butler 2005) and the anachelins (Walsby 1974a, b; Beiderbeck et al. 2000; Ito et al. 2004; Itou et al. 2001). The first two examples are derived from citrate and are relatively simple compounds, however, the anachelins are more complex and possess a mixed polyketide/peptide chain linked to a tetrahydroquinoline-type alkaloid fragment. The first members of the anachelin siderophore family to be isolated were anachelin $\mathrm{H}$ (1, Fig. 1) and anachelin-1 and were isolated in 1974 by Walsby and co-workers (Walsby 1974a, b). However, these compounds were not characterized until 2000, when Walsby, Budzikiewicz and coworkers reported the constitution of anachelin H (Beiderbeck et al. 2000). Shortly after this work, Murakami and co-workers

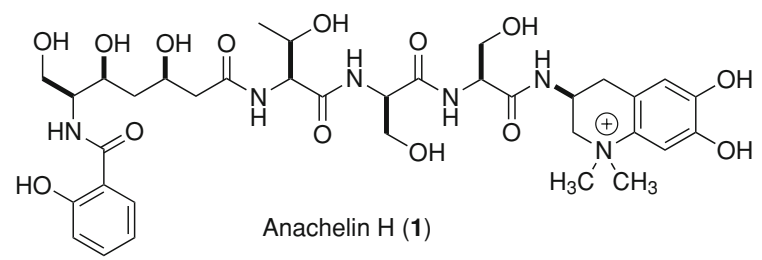

Fig. 1 Anachelin H (1), a siderophore from the cyanobacterium Anabaena cylindrica 1403-2a

reported the isolation and structural elucidation of anachelin-1, anachelin-2 and two related esters (Ito et al. 2004; Itou et al. 2001). We have investigated several aspects of anachelin-H (1) including its structure in solution (Gademann 2005; Barbaras and Gademann 2008), its biosynthesis (Gademann 2005) and its iron chelating properties (Bethuel and Gademann 2005). Furthermore, we have established its configuration through total synthesis (Gademann and Bethuel 2004a, b) and profiled its antimicrobial activity (Gademann et al. 2007). There is evidence that it is the catechol unit of anachelin that is responsible for iron binding (Bethuel and Gademann 2005), which led us to postulate that the catechol unit might also be able to bind to metal oxide surfaces. Support for this hypothesis stems from the work of McWhirter and Upritchard on the pyoverdin siderophores, which were shown to bind to metal oxide surfaces and were suggested to initiate biofilm formation (McWhirter et al. 2003; Upritchard et al. 2007). Further evidence that catechols bind to metal oxide surfaces can be found in the work on mussel adhesive proteins, which contain an unusually high amount of dihydroxyphenylalanine and are known to bind to metal oxide surfaces (Deming 1999). Following the pioneering studies of Waite and co-workers on mussel adhesive proteins (Waite and Tanzer 1981), several groups, including those of Grätzel (Moser et al. 1991; Rice et al. 2000), Messersmith (Dalsin et al. 2003; Lee et al. 2007), Wilker (Sever et al. 2004), Xu (Xu et al. 2004) and the Textor/Messersmith laboratories (Dalsin et al. 2005) have demonstrated the usefulness of catechols for surface modification (Chen et al. 2008). Based on our experience with anachelin- $\mathrm{H}$ and the literature precedent regarding mussel adhesive proteins, we demonstrated that compounds derived from the anachelin chromophore, e.g., 3 (Scheme 1), could also bind to metal oxide surfaces (Zürcher et al. 2006). 
Scheme 1 Preparation of Boc-protected anachelin chromophore $\mathbf{3}$ through an oxidative

heterofunctionalization of tyrosine derivative $\mathbf{2}$

(Gademann et al. 2007).

The first steps consist of enzymatic oxidation to the $o$-quinone 4, which is then intramolecularly trapped in a 1,4-addition either to the spiro compound $\mathbf{5}$ or the [4.4.0]-bicyclic ring system in 6. The spiro compound 5 can undergo a Djerassi dienone-phenol rearrangement to the dienone 6, which then tautomerizes to the anachelin chromophore $\mathbf{3}$<smiles>CN(C)C[C@H](Cc1ccc(O)cc1)NC(=O)OCc1ccccc1</smiles>

Hydroxylation, Oxidation

Aromatization<smiles>CN(C)C[C@H](CC1=CC(=O)C(=O)C=C1)NC(=O)OCc1ccccc1</smiles><smiles>CC(C)(C)OC(=O)NC1CC2(C=CC(=O)C(O)=C2)[N+](C)(C)C1</smiles>

\section{Preparation of anachelin chromophore 3}

We have developed several synthetic approaches for the preparation of anachelin chromophore 3 . The first approach starts from L-DOPA and following nitration and reduction affords a 2-oxo-tetrahydroquinoline system (Bethuel and Gademann 2005) and is based on a route developed previously by Kolasa and Miller (Kolasa and Miller 1990). However, this approach suffered from racemisation of the stereogenic center thus limiting its practicality. An improved method was realized through the use of an oxidative aza annulation reaction (Scheme 1) (Lawrence and Gademann 2008) and was based on a biosynthetic hypothesis (Gademann 2005; Gademann and Bethuel 2004a, b). While these first generation approaches started from the unnatural amino acid dihydroxyphenylalanine (DOPA) (Gademann 2005; Gademann and Bethuel 2004a, b), we were eventually able to overcome this limitation and start directly from tyrosine as shown in Scheme 1 (Gademann et al. 2007).

The starting material, tyrosine diamine 2 can be quickly obtained from commercially available BocL-Tyr-OH through amidation and reduction. This substrate is then smoothly converted using mushroom tyrosinase in the presence of oxygen to the anachelin chromophore, 3, in a single step. This interesting transformation, heterofunctionalization of the phenol ring, demonstrates the power of enzymatic catalysis in modern organic synthesis. Mechanistically, one can propose that the tyrosinase oxidizes the phenol to $o$-quinone 4, which can undergo an intramolecular 1 , 4 addition. Two pathways have been experimentally observed, the first proceeds through the spiro-[4.5] hydroxydienone, $\mathbf{5}$, and the second through the bicyclo-[4.4.0] hydroxydienone, 6. Following the course of the reaction by UV spectroscopy indicated that spiro compound $\mathbf{5}$ builds up during the early phase of the reaction, but is later converted to the more stable bicyclo derivative $\mathbf{6}$ through a Djerassi dienone-phenol rearrangement (Gademann 2005). In this respect, it should be noted that whereas the corresponding dienones lacking the 5-OH group are isolable (Mizutani et al. 2004), the 5-OH group in spiro 5 could facilitate intramolecular proton transfer thus accelerating the conversion to $\mathbf{6}$. Tautomerization of $\mathbf{6}$ leads to the desired product, $\mathbf{3}$, which was isolated in good yield. In the context of mechanistic studies, it was found that product $\mathbf{3}$ activates the enzyme responsible for its own formation through product activation. This route thus provides an 
elegant approach for the biocatalytic preparation of the anachelin chromophore.

\section{Protein resistant surfaces based on the anachelin chromophore and dopamine derivatives}

A significant problem related to a wide area ranging from biomedical devices and biosensors to marine technology is the nonspecific adsorption of biological macromolecules (proteins, carbohydrates) or microorganisms (bacteria, fungi) to surfaces, commonly called biofouling (Costerton et al. 1995; Hall-Stoodley et al. 2004). This process is also a frequent cause of nosocomial infections (Cunnion et al. 2001; Higashi et al. 1998), which are considered a leading cause of pathogen-related deaths in hospitals.

A promising strategy to combat biofouling is the generation of surfaces which are resistant or inert to this process (Yebra et al. 2004; Gademann 2007). To this end, several antifouling polymers such as polyethylene glycol (PEG) (Desai and Hubbell 1991; Lee et al. 1989; Prime and Whitesides 1991), polyglycerol (Siegers et al. 2004), poly(ethyleneoxide)-poly(propyleneoxide)/pluronics (Lee et al. 2000; Marsh et al. 2002), peptoids (Statz et al. 2005) and poly-2-methyl2-oxazoline (Konradi et al. 2008) have been developed. The problem of attaching these polymers to surfaces has been approached using various strategies including methods that rely on thiols (Prime and Whitesides 1991), silanes (Yang et al. 1999), and polyelectrolyte interactions with metals (Pasche et al. 2003), oxides and polymeric substrates, have been reported. The problem of wet adhesion, i.e., attachment under mild aqueous conditions remains a significant challenge. Thus, we chose to investigate the surface binding properties of anachelin chromophore 7 to titanium oxide surfaces with a view to developing a stable, protein-resistant (Zürcher et al. 2006) and cell-resistant (Wach et al. 2008a) nonfouling surface. It was decided to use $\mathrm{TiO}_{2}$ as it is frequently applied in the fields of medical devices and optical biosensors.

Anachelin chromophore PEG conjugate 7 contains a catechol moiety as the anchoring group, which is structurally similar to key elements of mussel-adhesive protein (MAPs) sequences (Deming 1999) that are thought to be responsible for the very strong wet adhesion of mussels to surfaces. Additionally, it contains a positive charge, which increases the affinity of this compound towards negatively charged metal oxide surfaces. Synthesis of polymer 7 was easily achieved starting from commercially available L-Tyr or L-DOPA and following the routes outlined above.

The PEG-anachelin conjugate 7 was adsorbed onto the $\mathrm{TiO}_{2}$ surface using an operationally simple dipand-rinse procedure in which the $\mathrm{TiO}_{2}$ plate is incubated in a dilute aqueous solution of $\mathbf{7}$ under cloud point conditions before being removed and thoroughly rinsed. This direct procedure is noteworthy as it avoids the use of surface chemistry and the problems associated with it, such as incomplete coupling and blocking of the remaining functionalities. The dip-and-rinse procedure resulted in dense packing of the PEG on the surface, maximizing the PEG surface density. The depth of the PEG layer on the metal surface, which is proportional to the amount of PEG adsorbed, was quantified using variable angle spectroscopic ellipsometry (VASE) and X-ray photoelectron spectroscopy (XPS) measurements (Zürcher et al. 2006). Thus, following the dip and rinse procedure and a short water rinse an adlayer thickness of about $3 \mathrm{~nm}$ was measured, which can be considered an excellent result. Moreover, when the coated sample was incubated under physiological conditions (HEPES 2 buffer, $\mathrm{pH} 7.4$ ) for $48 \mathrm{~h}$ the adlayer thickness was reduced by around $40 \%$ leaving a thickness of approximately $1.7 \mathrm{~nm}$. Finally, upon exposure to full human serum a reduction of the protein adlayer thickness of over $95 \%$ versus untreated control surfaces was observed for the PEG-anachelin conjugate 7 (Zürcher et al. 2006). When comparing compounds $\mathbf{7 - 1 0}$, the measured adlayer thickness after buffer incubation was highest for PEG-anachelin conjugate 7, and protein resistance was achieved with both $\mathbf{7}$ and $\mathbf{8}$. In addition, PEGanachelin conjugate 7 was also found to be stable against aerobic oxidation after exposure to air at room temperature resulted in no change by UV/VIS spectroscopy. This is in contrast to dopamine derived $\mathbf{8}$, which is known to form melanin-type, dark and insoluble polymers when exposed to oxygen (Mason 1965). Based on this experimental evidence, anachelin chromophore PEG conjugate 7 stands out due to its excellent binding properties, protein resistance and stability when compared to control polymers 8,9 and 10 (Fig. 2). 
Fig. 2 The anachelin chromophore PEG conjugate 7 , and control polymers 8-10<smiles>COCCOCC(=O)N[C@H]1Cc2cc(O)c(O)cc2[N+](C)(C)C1</smiles><smiles>CCOCCOCC(=O)N[C@@H](COCC)C[n+]1ccc(O)c(O)c1</smiles><smiles>COCCOCC(C)COCC(=O)NCCc1ccc(O)c(O)c1</smiles><smiles>COCCOCC(=O)N[C@@H](Cc1ccc(O)c(O)c1)C(=O)[O-]</smiles>

Fig. 3 Polymers 7, 13 and 14 allow for the generation of antifouling surfaces, polymers $\mathbf{1 1}$ and $\mathbf{1 2}$ featuring a dimethylamino group are not efficient in achieving this goal (Wach et al. 2008b)<smiles>CN(C)C[C@H](Cc1ccc(O)c(O)c1)NC(=O)Cl</smiles>

11

non protein resistant<smiles>CCN[C@@H](Cc1ccc(O)c(O)c1)C[N+](C)(C)C</smiles>

13

protein resistant<smiles>[C-]#[P+]N[C@@H](Cc1ccc(O)c(O)c1)C(=O)N[C@H](Cc1ccc(O)c(O)c1)CN(C)C</smiles>

12<smiles>[C-]#[N+]N[C@H]1Cc2cc(O)c(O)cc2[N+](C)(C)C1</smiles>

7 protein resistant<smiles>[C-]#[P+]NC(CCC(=O)NCCc1ccc(O)c(O)c1)C(=O)NCCc1ccc(O)c(O)c1</smiles>
14 protein resistant
In order to examine which structural features of anachelin 7 are required for efficient surface binding, a series of anachelin analogs, compounds 11-14 (Wach et al. 2008b), were synthesized and evaluated for their surface binding and antifouling properties. These analogs can be prepared more efficiently than the anachelin chromophore $\mathbf{3}$ itself and would thus offer advantages for large-scale production.

In the context of this structure activity relationship study, anchors featuring a dimethylaminomethylene unit, i.e., compounds $\mathbf{1 1}$ and 12, did not show any antifouling properties. In contrast, anchors containing an ammonium-derived dopamine, i.e., compound $\mathbf{1 3}$ (and the parent compound 7), or a divalent bisdopamine unit such as in 14, were highly efficient in achieving protein resistant surfaces (Wach et al. 2008b). Thus, using the dip-and-rinse procedure described above for the PEG-anachelin conjugate $\mathbf{7}$, polymers 13 and 14 were spontaneously adsorbed on to negatively charged $\mathrm{TiO}_{2}$ surfaces and both displayed extremely high adlayer thickness. These surfaces were then exposed to physiological conditions for $24 \mathrm{~h}$ after which time the adlayer thickness was found to have decreased to 1.7 and $1.8 \mathrm{~nm}$, respectively, for quaternary ammonium polymer $\mathbf{1 3}$ and divalent dopamine derivative 14. Finally, these surfaces were evaluated for their protein resistance properties by exposure of the polymer-coated surfaces to human serum for twenty minutes. The results showed that surfaces coated with either polymer $\mathbf{1 3}$ or 14 efficiently reduce nonspecific serum adsorption when compared with bare $\mathrm{TiO}_{2}$. In conclusion, dopamine-derived compounds 7, 13 and 14 all display excellent properties for surface functionalization and can be readily prepared in straightforward processes (Fig. 3). 


\section{Antimicrobial surfaces through natural product hybrids}

Secondary infections acquired in hospitals and other medical care centers are rising at an alarming rate (Stone et al. 2005; Cardo et al. 2004; Burke 2003; Leape et al. 1991). Such nosocomial infections are currently among the top causes of death in the US according to a recent survey (Starfield 2000). Increasing resistance of pathogens to commonly employed antibiotics is adding further complications to this problem (Costerton et al. 1995, 1999; Gold and Moellering 1996; Mah and O'toole 2001; Stewart and Costerton 2001; Walsh 2000). In addition, encapsulation of implants by tissue massively hampers the activity of antibiotics, as these may not reach their site of action leading to a decrease in activity of up to three orders of magnitude (Costerton et al. 1995, 1999; Mah and O'toole 2001; Rodriguez-Martinez and Pascual 2006). An appealing strategy to circumvent these problems would be the attachment of antibiotics to the implant surface, i.e., via the generation of antimicrobial surfaces (Antoci et al. 2007a, b; Edupuganti et al. 2007; Jose et al. 2005; Statz et al. 2008; Klibanov 2007). Benefits of this approach would include (1) High concentrations of antibiotics where they are needed thus maximizing impact and minimizing side effects (Roosenberg et al. 2000) (2) Decreased possibility of developing resistance, as there is no systemic release of antibiotic in the organism due to the covalent attachment (3) Surfaces can be tailored to accommodate several antibiotics or could be used as combination therapies by immobilizing compounds with differing biological activities, e.g., growth factors for human cells alongside antibiotics.

Based on the mild and selective surface binding properties of anachelin chromophores $\mathbf{7}$ and $\mathbf{1 3}$ (Zürcher et al. 2006; Wach et al. 2008b), we wondered whether the PEG terminus could be functionalized with a biologically active molecule such as an antibiotic. There were several questions that would need to be addressed when utilizing this approach. (1) Can the antibiotic still display activity or is its mode of action hampered by immobilization? (2) Are the resulting surfaces still protein and cell resistant and will the debris of the dead cells remain attached to the surface and thus diminish biological activity? (3) Can the antibiotic be attached to the surface without any leaching? (4) Does the polyfunctional nature of the complex antibiotic impact the surface modification potential of the anachelin chromophore?

In order to investigate the above questions we chose the highly complex glycopeptide antibiotic vancomycin for immobilization. There were several reasons for this, its well-studied mode of action (Kahne et al. 2005): its site of inhibition (the cell wall biosynthesis) (Kahne et al. 2005) and its densely functionalized architecture, which poses challenges to the other immobilization techniques, e.g., silane (Yang et al. 1999) or thiol (Love et al. 2005).

The synthesis of the vancomycin-PEG-anachelin chromophore hybrid, 16, was straightforward and began with Boc-deprotection of anachelin chromophore 3 and subsequent coupling to the N-hydroxysuccinidylester of Fmoc-PEG-propionate to afford compound 15. Removal of the Fmoc group and coupling to vancomycin (HATU, DMF) (Xing et al. 2002) furnished, after purification by size-exclusion chromatography, the target compound $\mathbf{1 6}$ (Wach et al. 2008a). It should be pointed out that this antibiotic derivative can be prepared in a single day and in high yield. Surface immobilization was achieved using the simple dip-and-rinse procedure described earlier and the resulting functionalized surfaces were evaluated for their antimicrobial properties against the biofilmforming bacterium Bacillus subtilis ATCC 6633 (Dawes and Mandelstam 1970) using fluorescence microscopy after Live/Dead kit staining (Roth et al. 1997). The resulting coated surfaces were found to be efficient at inhibiting

B. subtilis, moreover, the debris of the lysed cells does not remain on the surface and can be washed away (Wach et al. 2008a). These results established that the vancomycin hybrid surface based on anachelin natural product hybrid $\mathbf{1 6}$ displays dual antimicrobial and cell/protein/DNA resistant properties. In addition, repeated cycles of exposure and washing indicated that virtually no leaching of the vancomycin occurred over five cycles, supporting the notion that the immobilized vancomycin is indeed able to kill $B$. subtilis. Furthermore, it was also shown that the biological activity which results in cell death is a direct consequence of the vancomycin fragment, as the corresponding surface lacking vancomycin retained its cell-resistance properties against $B$. subtil$i s$, but lost its antimicrobial effect (Scheme 2). 
<smiles>CN1CC(NC(C)(C)C)Cc2cc(O)c(O)cc21</smiles>

3

\section{1. $\mathrm{HCl} /$ Dioxane}

2. Fmoc-PEG-PSA

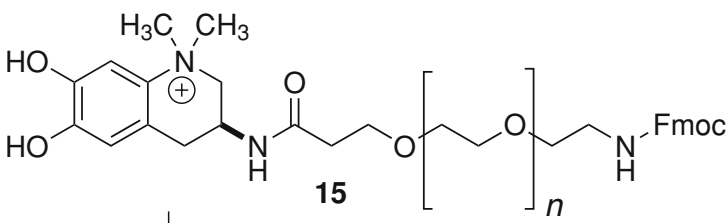

1. Piperidine, $\mathrm{DMF} / \mathrm{CH}_{2} \mathrm{Cl}_{2}$

2. Vancomycin, $\mathrm{HATU}, \mathrm{DMF} / \mathrm{CH}_{2} \mathrm{Cl}_{2}$

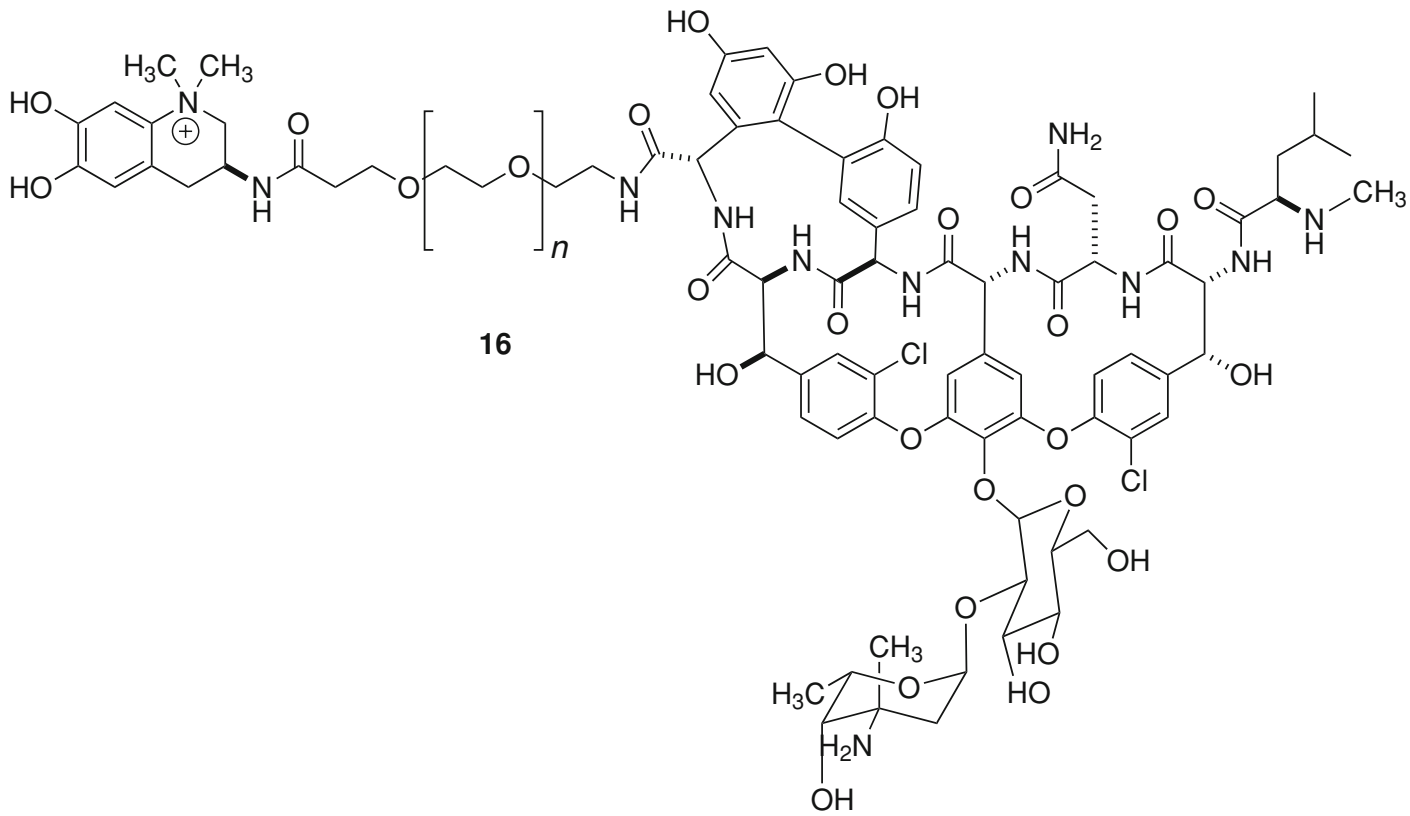

Scheme 2 Preparation of the anachelin chromophore-PEG-vancomycin hybrid $\mathbf{1 6}$

\section{Conclusion}

In this review we have shown how a natural product can serve as an inspiration to develop novel approaches in other research fields such as biomaterials design. Inspiration from nature was crucial in this approach as both the synthesis of the anachelin chromophore as well as the immobilization technique were based on bio-inspired strategies. The cyanobacterial siderophore, anachelin, serves as an excellent starting point for the design of effective surface anchors that allow for the immobilization of PEG (7) or PEG-vancomycin (16) on to surfaces. Hybridization of the anachelin chromophore to other biologically active compounds could allow for the generation of a wide range of surfaces which display various biological properties, allowing for the control of many biological processes.
Acknowledgments K.G. is a European Young Investigator (EURYI). Support of this work by the SNF is gratefully acknowledged (PE002-117136/1 and 200021-115918/1). We thank Prof. Dr. Marcus Textor, Barbora Malisova and Sina Saxer (ETH Zürich) and Dr. Stefan Zürcher and Dr. Samuele Tosatti (SurfaceSolutionS, Dübendorf) for the excellent collaboration.

\section{References}

Antoci V Jr, Adams CS, Hickok NJ, Shapiro IM, Parvizi J (2007a) Vancomycin bound to Ti rods reduces periprosthetic infection: Preliminary study. Clin Orthop Relat Res 461:88-95

Antoci V Jr, King SB, Jose B, Parvizi J, Zeiger AR, Wickstrom E, Freeman TA, Composto RJ, Ducheyne P, Shapiro IM, Hickok NJ, Adams CS (2007b) Vancomycin covalently bonded to titanium alloy prevents bacterial colonization. J Orthop Res 25:858-866. doi:10.1002/jor.20348

Barbaras D, Gademann K (2008) Stable beta turns of tripeptides in water through cation-pi interactions. Chembiochem 9:2398-2401. doi:10.1002/cbic.200800344 
Barbaras D, Kaiser M, Brun R, Gademann K (2008) Potent and selective antiplasmodial activity of the cyanobacterial alkaloid nostocarboline and its dimers. Bioorg Med Chem Lett 18:4413-4415. doi:10.1016/j.bmcl.2008.06.049

Becher PG, Beuchat J, Gademann K, Jüttner F (2005) Nostocarboline: Isolation and synthesis of a new cholinesterase inhibitor from Nostoc 78-12A. J Nat Prod 68:1793-1795. doi:10.1021/np0503121

Becher PG, Baumann HI, Gademann K, Jüttner F (2009) The cyanobacterial alkaloid nostocarboline: an inhibitor of acetylcholinesterase and trypsin. J Appl Phycol 21:103110. doi:10.1007/s10811-008-9335-3

Beiderbeck H, Taraz K, Budzikiewicz H, Walsby AE (2000) Anachelin, the siderophore of the cyanobacterium Anabaena cylindrica CCAP 1403/2A. Z Naturforsch C Biosci 55:681-687

Bethuel Y, Gademann K (2005) Synthesis and evaluation of the bis-nor-anachelin chromophore as potential cyanobacterial ligand. J Org Chem 70:6258-6264. doi:10.1021/ jo050674y

Blom JF, Brutsch T, Barbaras D, Bethuel Y, Locher HH, Hubschwerlen C, Gademann K (2006) Potent algicides based on the cyanobacterial alkaloid nostocarboline. Org Lett 8:737-740. doi:10.1021/o1052968b

Bonazzi S, Güttinger S, Zemp I, Kutay U, Gademann K (2007) Total synthesis, configuration, and biological evaluation of anguinomycin C. Angew Chem Int Ed 46:8707-8710. doi:10.1002/anie.200703134

Burja AM, Banaigs B, Abou-Mansour E, Burgess JG, Wright PC (2001) Marine cyanobacteria-a prolific source of natural products. Tetrahedron 57:9347-9377. doi:10.1016/S00404020(01)00931-0

Burke JP (2003) Infection control-a problem for patient safety. N Engl J Med 348:651-656. doi:10.1056/ NEJMhpr020557

Cardo D, Horan T, Andrus M, Dembinski M, Edwards J, Peavy G, Tolson J, Wagner D (2004) National nosocomial infections surveillance (NNIS) system report, data summary from January 1992 through June 2004, issued October 2004. Am J Infect Control 32:470-485. doi:10.1016/j.ajic. 2004.10.001

Carmichael WW (1992) Cyanobacteria secondary metabolitesthe cyanotoxins. J Appl Bacteriol 72:445-459

Carmichael WW (1994) The toxins of cyanobacteria. Sci Am 270:78-86

Chen Q, Jia Y, Liu S, Mogilevsky G, Kleinhammes A, Wu Y (2008) Molecules immobilization in titania nanotubes: a solid-state NMR and computational chemistry study. J Phys Chem C 112:17331-17335. doi:10.1021/jp8050593

Christiansen G, Yoshida WY, Blom JF, Portmann C, Gademann K, Hemscheidt T, Kurmayer R (2008) Isolation and structure determination of two microcystins and sequence comparison of the McyABC adenylation domains in planktothrix species. J Nat Prod 71:1881-1886. doi:10.1021/np800397u

Costerton JW, Lewandowski Z, Caldwell DE, Korber DR, LappinScott HM (1995) Microbial biofilms. Annu Rev Microbiol 49:711-745. doi:10.1146/annurev.mi.49.100195.003431

Costerton JW, Stewart PS, Greenberg EP (1999) Bacterial biofilms: a common cause of persistent infections. Science 284:1318-1322. doi:10.1126/science.284.5418.1318
Crichton R (2001) Inorganic biochemistry of iron metabolism: from molecular mechanism to clinical consequences, 2nd edn. Wiley, New York

Cunnion KM, Lee JC, Frank MM (2001) Capsule production and growth phase influence binding of complement to staphylococcus aureus. Infect Immun 69:6796-6803. doi:10.1128/IAI.69.11.6796-6803.2001

Dalsin JL, Hu B-H, Lee BP, Messersmith PB (2003) Mussel adhesive protein mimetic polymers for the preparation of nonfouling surfaces. J Am Chem Soc 125:4253-4258. doi: $10.1021 / \mathrm{ja0} 284963$

Dalsin JL, Lin LJ, Tosatti S, Voros J, Textor M, Messersmith PB (2005) Protein resistance of titanium oxide surfaces modified by biologically inspired mPEG-DOPA. Langmuir 21:640-646. doi:10.1021/la048626g

Dawes IW, Mandelstam J (1970) Sporulation of bacillus-subtilis in continuous culture. J Bacteriol 103:529-535

Deming TJ (1999) Mussel byssus and biomolecular materials. Curr Opin Chem Biol 3:100-105. doi:10.1016/S13675931(99)80018-0

Desai NP, Hubbell JA (1991) Solution technique to incorporate polyethylene oxide and other water-soluble polymers into surfaces of polymeric biomaterials. Biomaterials 12:144153. doi:10.1016/0142-9612(91)90193-E

Drechsel H, Jung G (1998) Peptide siderophores. J Pept Sci 4:147-181. doi:10.1002/(SICI)1099-1387(199805)4:3 $<147$ ::AID-PSC136>3.0.CO;2-C

Edupuganti OP, Antoci V, King SB, Jose B, Adams CS, Parvizi J, Shapiro IM, Zeiger AR, Hickok NJ, Wickstrom E (2007) Covalent bonding of vancomycin to Ti6Al4 V alloy pins provides long-term inhibition of Staphylococcus aureus colonization. Bioorg Med Chem Lett 17:26922696. doi:10.1016/j.bmcl.2007.03.005

Gademann K (2005) Mechanistic studies on the tyrosinasecatalyzed formation of the anachelin chromophore. Chembiochem 6:913-919. doi:10.1002/cbic.200400343

Gademann K (2006) Natural product hybrids. Chimia (Aarau) 60:841-845. doi:10.2533/chimia.2006.841

Gademann K (2007) Cyanobacterial natural products for the inhibition of biofilm formation and biofouling. Chimia (Aarau) 61:373-377. doi:10.2533/chimia.2007.373

Gademann K, Bethuel Y (2004a) A biomimetic route to the peptide alkaloid anachelin. Angew Chem Int Ed 43:33273329. doi:10.1002/anie.200453909

Gademann K, Bethuel Y (2004b) Total synthesis of anachelin H. Org Lett 6:4707-4710. doi:10.1021/o1048068x

Gademann K, Portmann C (2008) Secondary metabolites from cyanobacteria: complex structures and powerful bioactivities. Curr Org Chem 12:326-341. doi:10.2174/1385 27208783743750

Gademann K, Bethuel Y, Locher HH, Hubschwerlen C (2007) Biomimetic total synthesis and antimicrobial evaluation of anachelin H. J Org Chem 72:8361-8370. doi:10.1021/ jo701402b

Gold HS, Moellering RC (1996) Drug therapy-antimicrobialdrug resistance. $\mathrm{N}$ Engl J Med 335:1445-1453. doi: 10.1056/NEJM199611073351907

Goldman SJ, Lammers PJ, Berman MS, Sanders-Loehr J (1983) Siderophore-mediated iron uptake in different strains of Anabaena sp. J Bacteriol 156:1144-1150 
Hall-Stoodley L, Costerton JW, Stoodley P (2004) Bacterial biofilms: from the natural environment to infectious diseases. Nat Rev Microbiol 2:95-108. doi:10.1038/nrmicro821

Harada K (2004) Production of secondary metabolites by freshwater cyanobacteria. Chem Pharm Bull (Tokyo) 52:889-899. doi:10.1248/cpb.52.889

Herrero A, Flores E (eds) (2008) The cyanobacteria: molecular biology, genomics and evolution. Caister Academic Press, Sevilla

Higashi JM, Wang IW, Shlaes DM, Anderson JM, Marchant RE (1998) Adhesion of Staphylococcus epidermidis and transposon mutant strains to hydrophobic polyethylene. J Biomed Mater Res 39:341-350. doi:10.1002/(SICI)10974636(19980305)39:3<341::AID-JBM1>3.0.CO;2-J

Ito Y, Butler A (2005) Structure of synechobactins, new siderophores of the marine cyanobacterium Synechococcus sp PCC 7002. Limnol Oceanogr 50:1918-1923

Ito Y, Ishida K, Okada S, Murakami M (2004) The absolute stereochemistry of anachelins, siderophores from the cyanobacterium Anabaena cylindrica. Tetrahedron 60: 9075-9080. doi:10.1016/j.tet.2004.07.105

Itou Y, Okada S, Murakami M (2001) Two structural isomeric siderophores from the freshwater cyanobacterium Anabaena cylindrica (NIES-19). Tetrahedron 57:9093-9099. doi:10.1016/S0040-4020(01)00934-6

Jose B, Antoci V, Zeiger AR, Wickstrom E, Hickok NJ (2005) Vancomycin covalently bonded to titanium beads kills Staphylococcus aureus. Chem Biol 12:1041-1048. doi: 10.1016/j.chembiol.2005.06.013

Kahne D, Leimkuhler C, Lu W, Walsh C (2005) Glycopeptide and lipoglycopeptide antibiotics. Chem Rev 105:425-448. doi:10.1021/cr030103a

Keller-Schierlein W, Prelog V, Zähner H (1964) Siderochrome. (Natürliche Eisen(III)-trihydroxamat-Komplexe). Fortschr Chem Org Naturst 22:279-322

Klibanov AM (2007) Permanently microbicidal materials coatings. J Mat Chem 17:2479-2482. doi: 10.1039/b702079a

Kolasa T, Miller MJ (1990) Synthesis of the chromophore of pseudobactin, a fluorescent siderophore from Pseudomonas. J Org Chem 55:4246-4255. doi:10.1021/jo00301a008

Konradi R, Pidhatika B, Mühlebach A, Textor M (2008) Poly2-methyl-2-oxazoline: A peptide-like polymer for proteinrepellent surfaces. Langmuir 24:613-616. doi:10.1021/ la702917z

Lammers PJ, Sanders-Loehr J (1982) Active transport of ferric schizokinen in anabaena sp. J Bacteriol 151:288-294

Lawrence AK, Gademann K (2008) Aza-annulation strategies in alkaloid total synthesis. Synthesis 331-351. doi:10.1055/s2008-1032134

Leape LL, Brennan TA, Laird N, Lawthers AG, Localio AR, Barnes BA, Hebert L, Newhouse JP, Weiler PC, Hiatt H (1991) The nature of adverse events in hospitalizedpatients-results of the harvard medical-practice study. $\mathrm{N}$ Engl J Med 324:377-384

Lee JH, Kopecek J, Andrade JD (1989) Protein-resistant surfaces prepared by PEO-containing block copolymer surfactants. J Biomed Mater Res 23:351-368. doi:10.1002/ jbm. 820230306

Lee JH, Ju YM, Kim DM (2000) Platelet adhesion onto segmented polyurethane film surfaces modified by addition and crosslinking of PEO-containing block copolymers.
Biomaterials 21:683-691. doi:10.1016/S0142-9612(99) 00197-0

Lee H, Dellatore SM, Miller WM, Messersmith PB (2007) Mussel-inspired surface chemistry for multifunctional coatings. Science 318:426-430. doi:10.1126/science. 1147241

Love JC, Estroff LA, Kriebel JK, Nuzzo RG, Whitesides GM (2005) Self-assembled monolayers of thiolates on metals as a form of nanotechnology. Chem Rev 105:1103-1169. doi:10.1021/cr0300789

Luesch H, Harrigan GG, Goetz G, Horgen FD (2002) The cyanobacterial origin of potent anticancer agents originally isolated from sea hares. Curr Med Chem 9:17911806

Mah TFC, O'toole GA (2001) Mechanisms of biofilm resistance to antimicrobial agents. Trends Microbiol 9:34-39. doi:10.1016/S0966-842X(00)01913-2

Marsh LH, Coke M, Dettmar PW, Ewen RJ, Havler M, Nevell TG, Smart JD, Smith JR, Timmins B, Tsibouklis J, Alexander C (2002) Adsorbed poly(ethyleneoxide)-poly (propyleneoxide) copolymers on synthetic surfaces: Spectroscopy and microscopy of polymer structures and effects on adhesion of skin-borne bacteria. J Biomed Mater Res 61:641-652. doi:10.1002/jbm.10174

Mason HS (1965) Oxidases. Annu Rev Biochem 34:595-634. doi:10.1146/annurev.bi.34.070165.003115

McWhirter MJ, Bremer PJ, Lamont L, McQuillan A (2003) Siderophore-mediated covalent bonding to metal (oxide) surfaces during biofilm initiation by pseudomonas aeruginosa bacteria. Langmuir 19:3575-3577. doi:10.1021/ la020918z

Mizutani H, Takayama J, Soeda Y, Honda T (2004) A formal synthesis of a muscarinic M1 receptor antagonist, (-)TAN1251A. Heterocycles 62:343-355. doi:10.3987/COM$03-\mathrm{S}(\mathrm{P}) 14$

Moser J, Punchihewa S, Infelta PP, Grätzel M (1991) Surface complexation of colloidal semiconductors strongly enhances interfacial electron-transfer rates. Langmuir 7:3012-3018. doi:10.1021/la00060a018

Namikoshi M, Rinehart KL (1996) Bioactive compounds produced by cyanobacteria. J Ind Microbiol Biotechnol 17:373-384. doi:10.1007/BF01574768

Pasche S, De Paul SM, Vörös J, Spencer ND, Textor M (2003) Poly(l-lysine)-graft-poly(ethylene glycol) assembled monolayers on niobium oxide surfaces: a quantitative study of the influence of polymer interfacial architecture on resistance to protein adsorption by ToF-SIMS and in situ OWLS. Langmuir 19:9216-9225. doi:10.1021/la034111y

Portmann C, Blom JF, Gademann K, Jüttner F (2008a) Aerucyclamides $\mathrm{A}$ and $\mathrm{B}$ : isolation and synthesis of toxic ribosomal heterocyclic peptides from the cyanobacterium microcystis aeruginosa PCC 7806. J Nat Prod 71:11931196. doi:10.1021/np800118g

Portmann C, Blom JF, Kaiser M, Brun R, Jüttner F, Gademann $\mathrm{K}$ (2008b) Isolation of aerucyclamides C and D and structure revision of microcyclamide 7806A: heterocyclic ribosomal peptides from microcystis aeruginosa PCC 7806 and their antiparasite evaluation. J Nat Prod 71:1891-1896. doi:10.1021/np800409z

Portmann C, Prestinari C, Myers T, Scharte J, Gademann K (2009) Directed biosynthesis of phytotoxic alkaloids in 
the cyanobacterium nostoc 78-12A. Chembiochem 10:889-895. doi:10.1002/cbic.200800837

Prime KL, Whitesides GM (1991) Self-assembled organic monolayers: model systems for studying adsorption of proteins at surfaces. Science 252:1164-1167. doi:10.1126/ science. 252.5009 .1164

Raymond KN, Müller G, Matzanke BF (1984) Complexation of iron by siderophores: a review of their solution and structural chemistry and biological function. Top Curr Chem 123:49-102

Rice CR, Ward MD, Nazeeruddin MK, Grätzel M (2000) Catechol as an efficient anchoring group for attachment of ruthenium-polypyridine photosensitisers to solar cells based on nanocrystalline $\mathrm{TiO} 2$ films. New J Chem 24:651-652. doi:10.1039/b003823g

Rodriguez-Martinez JM, Pascual A (2006) Antimicrobial resistance in bacterial biofilms. Rev Med Microbiol 17:65-75

Roosenberg JM 2nd, Lin YM, Lu Y, Miller MJ (2000) Studies and syntheses of siderophores, microbial iron chelators, and analogs as potential drug delivery agents. Curr Med Chem 7:159-197

Roth BL, Poot M, Yue ST, Millard PJ (1997) Bacterial viability and antibiotic susceptibility testing with SYTOX green nucleic acid stain. Appl Environ Microbiol 63: 2421-2431

Sever MJ, Weisser JT, Monahan J, Srinivasan S, Wilker JJ (2004) Metal-mediated cross-linking in the generation of a marine-mussel adhesive. Angew Chem Int Ed 43:448450. doi:10.1002/anie.200352759

Siegers C, Biesalski M, Haag R (2004) Self-assembled monolayers of dendritic polyglycerol derivatives on gold that resist the adsorption of proteins. Chem Eur J 10:28312838. doi:10.1002/chem.200306073

Singh S, Kate BN, Banerjee UC (2005) Bioactive compounds from cyanobacteria and microalgae-an overview. Crit Rev Biotechnol 25:73-95. doi:10.1080/07388550500248498

Starfield B (2000) Is US health really the best in the world? JAMA 284:483-485. doi:10.1001/jama.284.4.483

Statz AR, Messersmith PB, Meagher RJ, Barron AE (2005) New peptidomimetic polymers for antifouling surfaces. J Am Chem Soc 127:7972-7973. doi:10.1021/ja0522534

Statz AR, Park JP, Chongsiriwatana NP, Barron AE, Messersmith PB (2008) Surface-immobilised antimicrobial peptoids. Biofouling 24:439-448. doi:10.1080/089270108 02331829

Stewart PS, Costerton JW (2001) Antibiotic resistance of bacteria in biofilms. Lancet 358:135-138. doi:10.1016/ S0140-6736(01)05321-1

Stone PW, Braccia D, Larson E (2005) Systematic review of economic analyses of health care-associated infections. Am J Infect Control 33:501-509. doi:10.1016/j.ajic.2005. 04.246
Upritchard HG, Yang J, Bremer PJ, Lamont IL, McQuillan AJ (2007) Adsorption to metal oxides of the Pseudomonas aeruginosa siderophore pyoverdine and implications for bacterial biofilm formation on metals. Langmuir 23:71897195. doi:10.1021/la7004024

Wach JY, Bonazzi S, Gademann K (2008a) Antimicrobial surfaces through natural product hybrids. Angew Chem Int Ed 47:7123-7126. doi:10.1002/anie.200801570

Wach JY, Malisova B, Bonazzi S, Tosatti S, Textor M, Zürcher S, Gademann K (2008b) Protein-resistant surfaces through mild dopamine surface functionalization. Chem Eur J 14:10579-10584. doi:10.1002/chem.200801134

Waite JH, Tanzer ML (1981) Polyphenolic substance of mytilus edulis: novel adhesive containing L-dopa and hydroxyproline. Science 212:1038-1040. doi:10.1126/ science. 212.4498 .1038

Walsby AE (1974a) The extracellular products of anabaena cylindrica lemm. I. Isolation of a macromolecular pigmentpeptide complex. Br Phycol J 9:371-381. doi:10.1080/ 00071617400650441

Walsby AE (1974b) The extracellular products of Anabaena cylindrica Lemm. II. Fluorescent substances containing serine and threonine and their role in extracellular pigment formation. Br Phycol J 9:383-391. doi:10.1080/ 00071617400650451

Walsh C (2000) Molecular mechanisms that confer antibacterial drug resistance. Nature 406:775-781. doi:10.1038/ 35021219

Xing B, Yu C-W, Chow K-H, Ho P-L, Fu D, Xu B (2002) Hydrophobic interaction and hydrogen bonding cooperatively confer a vancomycin hydrogel: a potential candidate for biomaterials. J Am Chem Soc 124:1484614847. doi:10.1021/ja028539f

Xu C, Xu K, Gu H, Guo Z, Xu B, Zheng R, Liu H, Zhang X (2004) Dopamine as a robust anchor to immobilize functional molecules on the iron oxide shell of magnetic nanoparticles. J Am Chem Soc 126:9938-9939. doi: 10.1021/ja0464802

Yang Z, Galloway JA, Yu H (1999) Protein interactions with poly(ethylene glycol) self-assembled monolayers on glass substrates: diffusion and adsorption. Langmuir 15:84058411. doi:10.1021/la990260y

Yebra DM, Kiil S, Dam-Johansen K (2004) Antifouling technology-past, present and future steps towards efficient and environmentally friendly antifouling coatings. Prog Org Coat 50:75-104. doi:10.1016/j.porgcoat.2003.06.001

Zürcher S, Wäckerlin D, Bethuel Y, Malisova B, Textor M, Tosatti S, Gademann K (2006) Biomimetic surface modifications based on the cyanobacterial iron chelator anachelin. J Am Chem Soc 128:1064-1065. doi:10.1021/ ja056256s 